\title{
Efek Ekstrak Daun Kembang Bulan (Tithonia diversifolia) terhadap Kadar Glukosa Darah Tikus Wistar (Rattus norvegicus) yang Diinduksi Alloxan
}

\author{
Fithri Wening Sasmita ${ }^{1}$, Eko Susetyarini ${ }^{1}$, Husamah ${ }^{1,}$ dan Yuni Pantiwati ${ }^{1}$ \\ ${ }^{1}$ Fakultas Keguruan dan IImu Pendidikan, Universitas Muhammadiyah Malang \\ Email : fitri.sasmita23@yahoo.com
}

\begin{abstract}
Diabetes Mellitus is a metabolic disease marked increase in blood sugar or hyperglycemia. Hyperglycemia occurs due to abnormalities in insulin secretion or insulin action. Alloxan induced diabetes with damaging cells of the pancreas and initiate the occurrence of hyperglycemia. One of the plants that have medicinal potential to decreasing of blood glucose its a Tithonia diversifolia leaves, which contains flavonoids and sesquiterpenes. The purpose of this research are (1) Analyzing the effect of Tithonia diversifolia leaves extract to decreasing blood glucose Wistar rats induced with alloxan; (2) Determining the effective dose of Tithonia diversifolia leaves extract in decreasing blood glucose Wistar rats. This is a True Experimental-Post Test Only Control Group Design referenced to Sambrook \& Russel. The samples used were twenty-five Wistar rats divided into 5 groups and 5 repetitions ie P1 (control), P2 (alloxan only), P3 (alloxan and dose of $1.28 \mathrm{ml} / 200 \mathrm{~g} \mathrm{BW}$ ), P4 (alloxan and dose of $2,57 \mathrm{ml} / 200 \mathrm{~g} \mathrm{BB}$ ) and P5 (alloxan and dose of $5.14 \mathrm{ml} / 200 \mathrm{~g} \mathrm{BB}$ ). The data analysis technique used One-way ANOVA followed by Duncan test.The research showed that there was an effect of Tithonia diversifolia leaves extract to decrease blood glucose levels of Wistar rats. It is concluded that Tithonia diversifolia leaves extract at dose 5,14 $\mathrm{ml} / 200 \mathrm{~g}$ BB has antidiabetic effect.
\end{abstract}

Key Words : diabetes mellitus, tithonia, alloxan, flavonoid

\begin{abstract}
Abstrak
Diabetes Mellitus merupakan penyakit metabolik yang ditandai kenaikan kadar gula darah atau hiperglikemia yang terjadi karena kelainan sekresi insulin atau kerja insulin. Alloxan menginduksi diabetes dengan merusak sel pankreas dan mengawali terjadinya hiperglikemia. Salah satu tumbuhan yang memiliki potensi penurunan glukosa darah adalah daun Tithonia diversifolia karena mengandung senyawa flavonoid dan seskuiterpen. Tujuan penelitian ini adalah (1) menganalisis efek ekstrak daun kembang bulan terhadap penurunan kadar glukosa darah tikus Wistar; dan (2) menentukan pemberian ekstrak daun kembang bulan yang memiliki pengaruh efektif dalam penurunan kadar glukosa darah tikus Wistar. Rancangan yang digunakan adalah True Experimental-Post Test Only Control Group Design mengacu pada Sambrook \& Russel. Sampel yang digunakan adalah tikus Wistar sebanyak 25 ekor yang terbagi dalam 5 kelompok perlakuan dan 5 kali pengulangan yaitu P1 (kontrol), P2 (hanya alloxan), P3 (alloxan dan dosis $1,28 \mathrm{ml} / 200 \mathrm{~g} \mathrm{BB}$ ), P4 (aloxan dan dosis $2,57 \mathrm{ml} / 200 \mathrm{~g} \mathrm{BB}$ ), dan P5 (alloxan dan dosis 5,14 ml/200g BB). Analisis data menggunakan One-way ANOVA yang dilanjutkan uji Duncan. Hasil penelitian menunjukkan bahwa ada efek ekstrak daun kembang bulan terhadap penurunan kadar glukosa darah tikus Wistar. Daun kembang bulan memiliki efek antidiabetes atau berperan sebagai antihiperglikemik pada pemberian dosis sebesar 5,14 ml/200g BB.
\end{abstract}

Kata kunci : diabetes mellitus, tithonia, alloxan, flavonoid

\section{Pendahuluan}

Diabetes Mellitus (DM) merupakan penyakit metabolik yang ditandai kenaikan kadar gula darah atau hiperglikemia kronik (Powers, 2001). Hiperglikemia terjadi karena kelainan sekresi insulin, kerja insulin atau keduanya (Purnamasari, 2009).

WHO menggolongkan DM ke dalam kelompok penyakit kronis tidak menular dan diidap melalui gaya hidup (Putri \& Isfandiari, 2013). DM dapat menyerang segala umur dan sosial ekonomi. Perubahan gaya hidup mempengaruhi kebiasan dan pola makan masyarakat (Wild et al., 2004). DM menjadi penyakit global endemik (Shaw et al., 2010) dan masalah kesehatan utama dunia (Gheith et al., 2016). Indonesia menduduki posisi keempat dalam jumlah penderita DM terbanyak di dunia setelah India, Cina dan Amerika Serikat (Wild et al., 2004). Hasil Riset Kesehatan Dasar tahun 2013 menunjukkan jumlah absolut, yaitu penderita
DM sekitar 12.191.564 orang (Depkes RI, 2014). Hal ini menunjukkan besarnya jumlah penderita DM yang bila tak tertangani dapat mengurangi kualitas sumber daya manusia Indonesia (Indariani, 2011).

Penggunaan obat-obat hipoglikemik dapat menyebabkan beberapaefek samping. Berbagai efek samping obat kimia sintetik dan memerlukan biaya yang relatif mahal menyebabkan pengobatan tradisional mendapat tempat dimasyarakat dan menjadi alternatif pengobatan. Fenomena saat ini menunjukkan semakin banyak konsumen yang kembali ke alam termasuk dalam penggunaan obat antidiabetes.

Salah satu tumbuhan yang memiliki potensi obat adalah tanaman kembang bulan (Tithonia diversifolia A. Gray) (Hanum \&van der Masen, 2002). T. diversifolia secara tradisional digunakan sebagai obat sakit perut, kembung, diare, dan anti radang atau antiinflamasi (Dalimartha, 2000). Bagian tanaman $T$. diversifolia yang dimanfaatkan 
sebagai sumber zat kimia adalah daun, akar, batang, buah, dan biji (Verawati et al., 2011). Daun $T$. diversifolia mengandung senyawa alkaloid, terpenoid, flavonoid, saponin, tanin, polifenol, dan golongan seskuiterpen (Jamal \& Agusta, 1999). T. diversifolia merupakan tanaman yang digunakan masyarakat China untuk antidiabetes (Zhao et al., 2012). Dosis penggunaan daun $T$. diversifolia oleh masyarakat adalah 5 lembar setara $2 \mathrm{~g}$.

Pembuktian apakah ekstrak daun $T$. diversifolia dapat menurunkan kadar glukosa darah sangat penting, maka perlu dilakukan uji pada tikus yang diinduksi Alloxan. Alloxan menyebabkan kerusakan dan kematian sel islet pankreas dalam hewan percobaan, diabetes dan menurunkan atau menghentikan sekresi insulin. Kerja sitotoksik Alloxan ini diperantarai oleh Reactive Oxygen Species (ROS), dimana Alloxan dan produk reduksinya memasuki siklus redoks, dan membentuk produk samping radikal superoksida. Radikal ini mengalami dismutasi menjadi $\mathrm{H}_{2} \mathrm{O}_{2}$ menjadi radikal hidroksil yang sangat reaktif yang terbentuk melalui reaksi Fenton. Kerja ROS simultan dengan meningkatnya kadar kalsium sitosol yang menyebabkan cepat rusaknya sel $\beta$ pankreas (Winarsi et al., 2013).

Berdasarkan berbagai uraian di atas maka perlu kiranya dilakukan penelitian untuk membuktikan adanya efek ekstrak daun $T$. diversifolia terhadap kadar glukosa darah tikus Wistar (Rattus norvegicus) yang diinduksi alloxan.Tujuan penelitian ini adalah(1) menganalisis ekstrak daun $T$. diversifolia terhadap penurunan kadar glukosa darah tikus Wistar (Rattus norvegicus); (2) Menentukan pada pemberian ekstrak daun $T$. diversifolia berapakah yang memiliki pengaruh efektif dalam penurunan kadar glukosa darah tikus Wistar (Rattus norvegicus).

\section{Metode}

\section{Jenis Penelitian}

Jenis penelitian ini adalah eksperimental sesungguhnya secara in vivo yang dilakukan di laboratorium. Rancangan yang digunakan adalah True Experimental-Post Test Only Control Group Design mengacu pada Sambrook \& Russel (2001).

\section{Tempat dan Waktu Penelitian}

Penelitian dilaksanakan pada tanggal 14 Maret sampai 11 Juni 2016 bertempat di UPT Materai Medica Batu (ekstraksi terstandar) dan Laboratorium Kimia Universitas Muhammadiyah Malang (pemberian perlakuan dan uji glukosa darah).

\section{Populasi dan Sampel}

Populasi penelitian ini adalah tikus Wistar (Rattus norvegicus) berumur \pm 2 bulan dengan berat badan 100-200 gr. Sampel penelitian ini adalah tikus jantan yang berumur \pm 2 bulan sebanyak 25 ekor.

\section{Populasi dan Sampel}

Penelitian ini menggunakan Rancangan Acak Lengkap dengan 5 perlakuan (4 perlakuan uji dan 1 perlakuan kontrol) dan 5 kali ulangan sebagai berikut: (1) Kelompok I (P1): Tanpa perlakuan (kontrol). (2) Kelompok II (P2): Perlakuan hanya diinduksi alloxan $2 \mathrm{ml}$. (3) Kelompok III (P3): Perlakuan diinduksi alloxan 2 $\mathrm{ml}$ dan ekstrak daun kembang bulan dosis 1,28 $\mathrm{ml} / 200 \mathrm{~g}$ BB. (4) Kelompok IV (P4): Perlakuan diinduksi alloxan $2 \mathrm{ml}$ dan ekstrak daun kembang bulan dosis $2,57 \mathrm{ml} / 200 \mathrm{~g}$ BB. (5) Kelompok V (P5): Perlakuan diinduksi alloxan $2 \mathrm{ml}$ dan ekstrak daun kembang bulan dosis $5,14 \mathrm{ml} / 200 \mathrm{~g} \mathrm{BB}$.

\section{Prosedur Penelitian}

\section{Tahap Persiapan Alat dan Bahan}

Alat - alat yang digunakan dalam pemeliharaan adalah bak $(50 \times 40 \mathrm{~cm})$, kawat penutup, tempat makan dan minum. Alat-alat untuk membuat ekstrak daun kembang bulan adalah toples tertutup, corong gelas, timbangan analitik, gelas ukur, botol Schott, erlenmeyer, rotary evaporator, beaker glass, alkoholmeter, dan shaker digital. Alat-alat untuk menginduksikan alloxan pada tikus adalah spuit insulin $1 \mathrm{cc} / \mathrm{ml}$, dan sarung tangan. Alat-alat untuk memberikan ekstrak pada tikus adalah sonde dan suntikan 3 $\mathrm{ml}$. Alat-alat untuk menganalisis kadar glukosa darah adalah pisau bedah, glukometer tipe Digital GlucoDr ${ }^{\mathrm{TM}}$, dan GlucoDr ${ }^{\mathrm{TM}}$ Strip.

Bahan dalam pemeliharaan adalah pakan tikus BR-1, air minum, dan sekam. Bahan untuk membuat ekstrak adalah daun kembang bulan, etanol $96 \%$, dan kertas saring. Bahan untuk perlakuan adalah ekstrak daun kembang bulan, dan Alloxan. Bahan untuk analisis glukosa darah adalah serum darah tikus.

\section{Tahap Pelaksanaan}

Tahap pelaksanaan penelitian ini antara lain (1) Tahap pemeliharaan (Aklimatisasi selama 7 hari) yaitu tikus dimasukkan ke kandang, diberi makan sebanyak $10 \mathrm{gr} / 200 \mathrm{gr}$ BB tikus dan minum sebanyak $20 \mathrm{ml} / 200 \mathrm{gr}$ BB tikus setiap hari dan melakukan pembersihan dan perawatan kandang dengan cara mengganti sekam setiap 2 hari sekali; (2) Tahap membuat tikus Wistar hiperglikemia dengan cara diinduksi larutan alloxan $1,6 \%$ sebanyak $2 \mathrm{ml} /$ hari/ekor tikus selama 14 hari berturut-turut mulai hari ke-8 setelah aklimatisasi sampai hari ke-21. Untuk mengetahui tikus telah hiperglikemia dan 
mengetahui acuan mengukur penurunan kadar glukosa darah, maka dilakukan pengukuran menggunakan glukometer. (3) Tahap perlakuan dan pemberian ekstrak yaitu ekstrak daun kembang bulan diberikan sesuai frekuensi pemberian dosis selama 21 hari mulai hari ke-22 setelah aklimatisasi hingga hari ke-42. Menurut Sinaga et al. (2014) volume cairan maksimal yang dapat diberikan per oral pada tikus adalah $5 \mathrm{ml}$. Faktor konversi dosis dari manusia Eropa dengan berat badan $70 \mathrm{~kg}$ terhadap hewan uji (tikus) dengan berat badan $200 \mathrm{gr}$ adalah 0,018. Berat badan rata-rata orang Indonesia adalah $50 \mathrm{~kg}$.

Menurut Hidayat \& Napitupulu (2015) dosis penggunaan daun $T$. diversifolia sebagai obat tradisional bagi masyarakat adalah $2 \mathrm{~g}$. Dosis konversi tikus $=2000 \mathrm{mg} \times(70 \mathrm{~kg} / 50 \mathrm{~kg}) \times 0,018=$ $25,7 \mathrm{mg} / 200 \mathrm{~g} \mathrm{BB} /$ hari. Dalam penelitian ini digunakan dosis ekstrak daun kembang bulan yang bertingkat sebagaimana dijelaskan pada rancangan percobaan.

\section{Tahap Pengamatan}

Tahap pengukuran kadar glukosa darah tikus Wistar sesudah perlakuan pemberian ektrak daun kembang bulan: (1) Kadar glukosa darah di tentukan dengan menggunakan alat glukometer tipe GlukoDr ${ }^{T M}$; (2) Mengambil darah dari bagian ekor tikus, dengan cara ekor tikus dibersihkan lalu dipijat atau diurut perlahan-lahan, kemudian bagian ujung ditusuk dengan jarum (lancet); (3) Menempelkan darah yang keluar pada strip glukometer; (4) Kadar glukosa darah akan terukur dan nampak pada layar glukometer setelah 5 detik, dinyatakan dalam $\mathrm{mg} / \mathrm{dl}$.

\section{Teknik Pengumpulan Data}

Teknik yang digunakan untuk pengumpulan data dalam penelitian ini adalah teknik observasi yaitu teknik pengambilan data secara langsung dengan prosedur berencana yang melibatkan kegiatan melihat dan mencatat aktivitas tertentu. Observasi dilakukan terhadap penurunan kadar glukosa darah setelah diberi berbagai dosis ekstrak daun kembang bulan. Untuk memperoleh data penurunan kadar glukosa darah tikus Wistar dengan menggunakan alat digital GlukoDr ${ }^{\mathrm{TM}}$. Selanjutnya dimasukkan ke dalam tabel kadar glukosa darah tikus Wistar.

\section{Teknik Analisis Data}

Teknik analisis data yang digunakan adalah One-way ANOVA yang bertujuan untuk mengetahui ada tidaknya pengaruh dari perlakuan yang diberikan. Untuk melihat perlakuan yang paling efektif maka digunakan uji Duncan. sebelum uji ANOVA dan uji Duncan semua data yang diperoleh terlebih dahulu diuji prasyarat yaitu uji normalitas dan uji homogenitas. Semua proses analisis data dilakukan dengan bantuan SPSS 23 for Windows.

\section{Hasil dan Pembahasan}

Penelitian untuk mengetahui efek pemberian dosis ekstrak daun $T$. diversifolia terhadap kadar glukosa darah tikus Wistar yang diinduksi dengan alloxan secara in vivo telah dilakukan di laboratorium yang menggunakan kelompok perlakuan. Hasil penelitian menunjukkan bahwa kadar glukosa darah tikus pada masing-masing perlakuan berbeda-beda, sebagaimana ditunjukkan pada Tabel 1.

Tabel 1. Kadar Glukosa Darah Tikus Wistar pada Berbagai Perlakuan (Pengukuran hari ke-21 setelah perlakuan)

\begin{tabular}{|c|c|c|c|c|c|c|c|}
\hline \multirow{2}{*}{ Perlakuan } & \multicolumn{5}{|c|}{ Ulangan (mg/dl) } & \multirow{2}{*}{ Total } & \multirow{2}{*}{ Rerata } \\
\hline & 1 & 2 & 3 & 4 & 5 & & \\
\hline P1: Kelompok I (tanpa perlakukan/kontrol) & 126 & 113 & 119 & 124 & 129 & 611 & $122,2^{*}$ \\
\hline $\begin{array}{l}\text { P2: Kelompok II (perlakuan hanya diinduksi } \\
\text { alloxan) }\end{array}$ & 573 & 591 & 541 & 550 & 562 & 2817 & 563,4 \\
\hline $\begin{array}{l}\text { P3: Kelompok III (Perlakuan diinduksi } \\
\text { alloxan dan ekstrak 1,28 ml/200g BB) }\end{array}$ & 234 & 250 & 294 & 284 & 273 & 1335 & 267,0 \\
\hline $\begin{array}{l}\text { P4: Kelompk IV (Perlakuan diinduksi } \\
\text { alloxan dan ekstrak } 2,57 \mathrm{ml} / 200 \mathrm{~g} \mathrm{BB} \text { ) }\end{array}$ & 207 & 179 & 167 & 208 & 200 & 961 & 192,2 \\
\hline $\begin{array}{l}\text { P5: Kelompok V ((Perlakuan diinduksi } \\
\text { alloxan dan ekstrak } 5,14 \mathrm{ml} / 200 \mathrm{~g} \mathrm{BB})\end{array}$ & 148 & 102 & 130 & 141 & 163 & 684 & $136,8^{*}$ \\
\hline
\end{tabular}

Berdasarkan Tabel 1 tentang kadar glukosa darah tikus Wistar pada berbagai perlakuan dapat diketahui bahwa kadar glukosa darah dengan rerata tertinggi adalah pada kelompok II yaitu $563,4 \mathrm{mg} / \mathrm{dl}$ dan terendah adalah kelompok I yaitu $122,2 \mathrm{mg} / \mathrm{dl}$ (normal). Perlakuan yang memiliki rerata terendah atau mendekati normal adalah Kelompok V yaitu 136,8 mg/dl. Data hasil penelitian kadar glukosa darah tikus yang telah diperoleh selanjutnya diuji normalitas untuk melihat apakah data berdistribusi normal atau tidak. Apabila data telah memenuhi syarat 
normalitas maka selanjutnya diuji homogenitas untuk melihat varian data homogen atau tidak, lalu kemudian dilanjutkan pada analisis varian.

\section{Hasil Analisis Data Penelitian}

Hasil uji normalitas menunjukkan bahwa keseluruhan nilai probabilitas baik menggunakan statistika Kolmogorov-Smirnov (nilai Sig 0,200) maupun Shapiro-Wilk (nilai Sig antara 0,0243 sampai 0,926 ) lebih besar dari tingkat signifikasi $5 \%$. Dengan demikian asumsi kenormalan dipenuhi atau data berdistribusi normal. Hasil uji homogenitas me nunjukkan bahwa nilai probabilitas (nilai Sig. sebesar 0,169) lebih besar dari tingkat signifikasi $5 \%$, sehingga dapat dikatakan bahwa asumsi homogenitas varian dipenuhi (memiliki varian data yang sama atau homogen).

Pengujian hipotesis menggunakan OneWay ANOVA. Adapun hipotesis yang akan diuji, yaitu 1) Ada pengaruh ekstrak daun $T$. diversifolia terhadap penurunan kadar glukosa darah tikus
Wistar (Rattus norvegicus), dan 2) Pemberian dosis ekstrak daun $T$. diversifolia sebesar $5,14 \mathrm{ml}$ memiliki pengaruh paling efektif dalam penurunan kadar glukosa darah tikus Wistar. Hasil uji OneWay ANOVA ditunjukkan pada Tabel 2. Tabel 2 menunjukkan bahwa nilai sig $p=0,000<\alpha(0,05)$ yang berarti ada perbedaan sangat signifikan nilai rata-rata kadar glukosa darah diantara kelima kelompok perlakuan atau dengan kata lain varian populasi adalah tidak sama. Oleh karena itu, hipotesis nol $\left(\mathrm{H}_{0}\right)$ ditolak yang berarti ada pengaruh ekstrak daun $T$. diversifolia terhadap penurunan kadar glukosa darah tikus Wistar. Setelah diketahui bahwa ada pengaruh, maka dilanjutkan dengan Uji Duncan's. Uji Duncan's dilakukan untuk mengetahui tingkat perlakuan atau dosis yang paling efektif dalam menurunkan kadar glukosa darah tikus Wistar, hasil uji Duncan's ditunjukkan pada Tabel 3.

Tabel 2. Hasil Uji One Way ANOVA

\begin{tabular}{lrrrrr}
\hline & Sum of Squares & df & Mean Square & F & Sig. \\
\hline Between Groups & 653983.840 & 4 & 163495.960 & 432.895 & 0,000 \\
Within Groups & 7553.600 & 20 & 377.680 & & \\
Total & 661537.440 & 24 & & & \\
\hline
\end{tabular}

Catatan: $F_{\text {hitung }}>\mathrm{F}_{\text {tabel, }}$ maka $\mathrm{Ho}$ ditolak dan $\mathrm{Hi}$ diterima, artinya rata-rata populasi adalah tidak identik (sekurangkurangnya satu rata-rata tidak sama)

Tabel 3. Hasil Uji Duncan

\begin{tabular}{|c|c|c|c|c|c|}
\hline \multirow{2}{*}{ Perlakuan } & \multirow{2}{*}{$\mathrm{N}$} & \multicolumn{4}{|c|}{ Subset for alpha $=0.05$} \\
\hline & & 1 & 2 & 3 & 4 \\
\hline P1: Kelompok I (tanpa perlakukan/kontrol) & 5 & (a) & & & \\
\hline $\begin{array}{l}\text { P5: Kelompok V ((Perlakuan diinduksi Alloxan dan ekstrak 5,14 } \\
\mathrm{ml} / 200 \mathrm{~g} \mathrm{BB})\end{array}$ & 5 & (a) & & & \\
\hline $\begin{array}{l}\text { P4: Kelompk IV (Perlakuan diinduksi alloxan dan ekstrak 2,57 } \\
\mathrm{ml} / 200 \mathrm{~g} \mathrm{BB})\end{array}$ & 5 & & (b) & & \\
\hline $\begin{array}{l}\text { P3: Kelompok III (Perlakuan diinduksi alloxan dan ekstrak 1,28 } \\
\mathrm{ml} / 200 \mathrm{~g} \mathrm{BB})\end{array}$ & 5 & & & (c) & \\
\hline P2: Kelompok II (perlakuan hanya diinduksi alloxan) & 5 & & & & (d) \\
\hline
\end{tabular}

Keterangan : (a) : rata-rata P1 $<$ P5 $(122,20<136,80)=$ tidak berbeda nyata

(b) : rata-rata P4 > P5 $(192,20>136,80)=$ berbeda nyata

(c) : rata-rata P3 > P5 $(267,00>136,80)=$ berbeda nyata

(d) : rata-rata P2 > P5 $(192,20)>136,80)=$ berbeda nyata

Tabel 3 tentang hasil uji Duncan's menunjukkan bahwa rata-rata penurunan kadar glukosa darah tikus Wistar dengan glukosa darah mendekati normal adalah perlakuan $\mathrm{P} 5$, yaitu perlakuan Alloxan dan ekstrak daun $T$. diversifolia dengan dosis $5,14 \mathrm{ml}$ dengan nilai rata-rata 136,80 mg/dl. Pada perlakuan P1 (kontrol) dengan rata-rata $122,20 \mathrm{mg} / \mathrm{dl}$ dan P5 (dosis 5,14 $\mathrm{ml}$ ) dengan rata-rata $136,80 \mathrm{mg} / \mathrm{dl}$ keduanya tidak berbeda nyata, rata-rata kadar glukosa darah keduanya menunjukkan nilai yang signifikan apabila dibandingkan dengan perlakuan P2 (hanya alloxan) dengan rata-rata $536,40 \mathrm{mg} / \mathrm{dl}$.
Perlakuan P5 (dosis $5,14 \mathrm{ml}$ ) dengan rata-rata 136,80 berbeda nyata dibandingkan dengan perlakuan P3 (dosis 1,28 ml) dengan rata-rata $267,00 \mathrm{mg} / \mathrm{dl}$ dan P4 (dosis 2,57 ml) dengan ratarata $192,20 \mathrm{mg} / \mathrm{dl}$ karena kadar glukosa darahnya masih tinggi dibandingkan dengan perlakuan P1 (kontrol) dengan rata-rata $122,20 \mathrm{ml} / \mathrm{dg}$. Dengan demikian pemberian dosis ekstrak daun $T$. diversifolia sebesar $5,14 \mathrm{ml}$ memiliki pengaruh paling efektif dalam penurunan kadar glukosa darah tikus Wistar. 


\section{Pengaruh Ekstrak Daun Kembang Bulan Terhadap Penurunan Kadar Glukosa Darah Tikus Wistar}

Berdasarkan analisis terhadap hasil penelitian yang dilakukan oleh peneliti menggunakan one-way ANOVA menunjukan bahwa ada pengaruh ekstrak daun $T$. diversifolia terhadap penurunan kadar glukosa darah tikus Wistar. Hal ini menunjukkan bahwa daun $T$. diversifolia memiliki efek antidiabetes atau berperan sebagai antihiperglikemik. Menurut Chon et al. (2000) $T$. diversifolia memang mengandung dua komponen utama yang memiliki peran antidiabetik atau antihiperglikemik yaitu flavonoid dan seskuiterpen. Komponen flavonoid dan seskuiterpen paling banyak pada bagian daun.

Flavonoid diketahui memiliki aktifitas antioksidan yang berkaitan dengan aktifitas antidiabetes (Jagtap \& Bapat, 2010). Flavonoid diketahui memiliki aktifitas antioksidan yang diyakini mampu melindungi tubuh terhadap kerusakan yang disebabkan spesies oksigen reaktif, sehingga mampu menghambat terjadinya penyakit degeneratif seperti DM (Marianne et al., 2011). Terkait mekanisme penyembuhan penyakit diabetes, flavonoid diduga berperan secara signifikan meningkatkan aktivitas enzim antioksidan dan mampu meregenerasi sel-sel $\beta$ pankreas yang rusak sehingga defisiensi insulin dapat diatasi. Flavonoid yang terkandung di dalam tumbuhan diduga juga dapat memperbaiki sensitifitas reseptor insulin. Sehingga adanya flavonoid memberikan efek yang menguntungkan pada keadaan DM (Abdelmoaty et al.,2010).

Flavonoid dapat menurunkan kadar glukosa darah dengan kemampuannya sebagai zat antioksidan. Flavonoid bersifat protektif terhadap kerusakan sel $\beta$ sebagai penghasil insulin serta dapat mengembalikan sensitivitas reseptor insulin pada sel dan bahkan meningkatkan sensitivitas insulin (Winarsi et al.,2012). Antioksidan dapat menekan apoptosis sel $\beta$ tanpa mengubah proliferasi sel $\beta$ pankreas. Antioksidan dapat mengikat radikal bebas yang telah dibuktikan dalam beberapa penelitian, sehingga dapat mengurangi resistensi insulin (Ruhe \& McDonald, 2001).

Flavonoid yang diekstrak secara etanolik berpotensi menurunkan kadar glukosa darah pada tikus DM tipe 1 yang diinduksi Streptozotocin (STZ) dimana aktivitas enzim hepatik glukosa-6-fosfatase menurun secara nyata, ini membuktikan bahwa efek penurunan glukosa berhubungan dengan peningkatan metabolisme glukosa pada kelompok tikus yang diberikan flavonoid selama 21 hari (Zhang \& Tan, 2000; Syamsul et al., 2011). Tikus yang diberi perlakuan alloxan akan mengalami kerusakan sel pankreas dan menyebabkan hiperglikemia persisten. Sehubungan dengan itu menurut
Winarsi et al. (2012) flavonoid bekerja di luar pankreas. Flavonoid menstimulisai pemanfaatan glukosa perifer, dengan cara meningkatkan jalur glikolitik dan glikogenik, yang secara simultan menekan jalur glikogenolisis dan glukoneogenesis. Melalui mekanisme itu flavonoid dapat mengendalikan glukosa darah, sehingga kadar glukosa darah tikus menurun. Menurut Panjuantiningrum (2010) antioksidan pada flavonoid dapat menyumbangkan atom hidrogen. Flavonoid akan teroksidasi dan berikatan dengan radikal bebas sehingga radikal bebas menjadi senyawa lebih stabil.

Aktivitas antioksidan ini mampu menurunkan stress oksidatif sehingga mengurangi ROS (Reactive Oxygen Spesies). Menurut Widowati (2008) sumber stress oksidasi diabetes terjadi akibat perpindahan keseimbangan reaksi redoks karena perubahan metabolisme karbohidrat dan lipid yang akan meningkatkan pembentukan ROS dari reaksi glikasi dan oksidasi lipid, sehingga dapat menurunkan sistem pertahanan antioksidan.

Flavonoid mampu meregenerasi sel beta pankreas dan membantu merangsang sekresi insulin (Dheer \& Bhatnagar, 2010). Mekanisme lain dari flavonoid yang menunjukkan efek hipoglikemik yaitu mengurangi penyerapan glukosa dan mengatur aktivitas ekspresi enzim yang terlibat dalam metabolisme karbohidrat (Brahmachari, 2011). Ada beberapa mekanisme kerja obat hipoglikemik oral, yaitu meningkatkan sekresi insulin (golongan sulfonilurea), meningkatkan kepekaan reseptor insulin sehingga absorpsi glukosa di jaringan perifer meningkat, meningkatkan kepekaan insulin jaringan otot, jaringan lemak dan hati, serta menghambat penguraian polisakarida menjadi monosakarida. Flavonoid mempunyai mekanisme sama dengan obat hipoglikemik oral golongan sulfonilurea dalam menurunkan kadar glukosa darah tikus dengan cara meningkatkan sekresi insulin pada organ pankreas (Oktaria, 2013).

Flavonoid dapat mencegah komplikasi atau progresifitas DM dengan cara membersihkan radikal bebas yang berlebihan, memutuskan rantai reaksi radikal bebas, mengikat ion logam (chelating) dan memblokade jalur poliol dengan menghambat enzim aldose reduktase. Flavonoid juga memiliki efek penghambatan terhadap enzim a-gukosidase melalui ikatan hidroksilasi dan substitusi pada cincin $\beta$. Prinsip penghambatan ini serupa dengan acarbose yang selama ini digunakan sebagai obat untuk penanganan diabetes mellitus, yaitu dengan menghasilkan penundaan hidrolisis karbohidrat, disakarida dan absorpsi glukosa serta menghambat metabolisme sukrosa menjadi glukosa dan fruktosa (Ridwan et al., 2012; Taufiqurohman, 2015). Flavonoid merupakan senyawa inhibitor yang kuat terhadap enzim a-amilase yang berfungsi untuk 
pemecahan karbohidrat. Daya inhibisi enzim ini menyebabkan proses pemecahan dan absorbsi karbohidrat akan terganggu, sehingga kadar gula darah dapat diturunkan (Yulianty et al., 2015).

$T$. diversifolia juga memiliki komponen yang disebut seskuiterpen yang berfungsi mengurangi ketidaksensitifan terhadap insulin (Miura et al., 2002). Seskuiterpen secara signifikan mampu meningkatkan metabolisme glukosa tanpa efek toksik pada adiposit (Zhao et al., 2012). Seskuiterpen dapat menghambat faktor inflamasi pada sel mesangial ginjal manusia dalam kondisi hiperglikemik (Wang et al., 2010).

Seskuiterpen yang diisolasi dari ekstrak daun $T$. diversifolia dilaporkan memiliki daya sebagai agen fitoterapetik melawan infeksi bakteri pada organ (Pradeep et al., 2010). Seskuiterpen yang diisolasi dari tanaman menunjukkan aktivitas penghambat a-glukosidase yang signifikan (Choudhary, 2001). Seskuiterpen juga bisa menghambat ekspresi induksi glukosa tinggi pada inflamasi sitokinin pada sel mesangial manusia.

Mekanisme kerja seskuiterpen yang kedua adalah terkait dengan kemampuannya dalam menghambat (Inhibit) Advanced Oxidation Protein Product-Induced MCP-1 Expression in Podocytes. Advanced oxidation protein products (AOPPs) pertama kali ditemukan dan dilaporkan sebagai racun uremik oleh Witko-SARSAT dan ditemukan hubungannya dengan diabetes (Piwowar et al., 2009). AOPPs adalah produk protein yang mengandung dityrosine dan terbentuk selama stres oksidatif oleh reaksi protein serum dengan oksidan diklorinasi (Witko-Sarsat, 1998). Studi terbaru menemukan bahwa akumulasi kronis AOPPs menyebabkan peradangan di kedua ginjal pada penderita diabetes dan nondiabetes dengan meningkatkan secara signifikan dan berlebih infiltrasi makrofag (Li et al., 2007). AOPPs juga dapat menurunkan ekspresi nefrin dan podocin di podocytes, sehingga terjadi podocyte apoptosis dan penghapusan (Yanget al., 2010).

Seskuiterpen telah dilaporkan menunjukkan efek anti-inflamasi dengan menghambat IKK dan IkBa fosforilasi dan mempengaruhi kemampuan mengikat DNA (Saadane et al., 2007). Penelitian lain telah menunjukkan bahwa seskuiterpen melakukanblok MCP-1 mRNA dan ekspresi protein dengan menghambat aktivitas NF-kB dalam glomerulonefritis eksperimental dan sel mesangial ginjal manusia serta di podocytes (Sanchez-Niño et al., 2013). Seskuiterpen secara efektif dapat menipiskan dan mengaktivasi AOPPdiinduksi NF-kB, degradasi IkBa, dan ekspresi MCP-1 yang dirangsang tinggi glukosa pada sel mesangial tikus (Wang et al., 2013).

Berdasarkan berbagai uraian di atas dapat dikatakan bahwa $T$. diversivolia memiliki efek terhadap metabolisme glukosa melalui berbagai mekanisme termasuk dalam fungsinya yang seperti subtansi insulin, menghambat aktivitas insulinase, meningkatkan sekresi insulin dari sel $\beta$-pankreas atau dari sumber insulin, dan memungkinkan peningkatan regenerasi sel pankreas. Menurut Thongsom et al. (2013) T. diversivolia memang merupakan sumber antioksidan, dapat meningkatkan metabolisme glukosa, dan mampu mereduksi elevasi profil lipid dan peroksidasi lipid.

\section{Dosis Ekstrak Daun Kembang Bulan yang Memiliki Pengaruh Paling Efektif}

Hasil analisis menggunakan uji Duncan's menunjukkan bahwa pemberian dosis ekstrak daun kembang bulan ( $T$. diversifolia) sebesar 5,14 $\mathrm{ml}$ memiliki pengaruh paling efektif dalam penurunan kadar glukosa darah tikus Wistar. Perlakuan dengan dosis $5,14 \mathrm{ml}$ memiliki nilai rata-rata $136,80 \mathrm{mg} / \mathrm{dl}$ atau tidak berbeda nyata dengan perlakuan kontrol negatif atau normal dengan rata-rata $122,20 \mathrm{mg} / \mathrm{dl}$. Dosis ekstrak daun kembang bulan sebesar 5,14 $\mathrm{ml}$ merupakan dosis yang berpotensi untuk direkomendasikan karena mendekati normal.

Suatu dosis yang memiliki efek mendekati normal menunjukkan bahwa senyawa aktif yang terkandung di dalamnya terkonsentrasi efektif optimum, sedangkan pada dosis lain masih kurang sehingga mempunyai efek yang kurang efektif dan tidak memadai, sehingga efek antihiperglikemik yang muncul lebih kecil (Fidrianny et al., 2003). Telah diketahui sebelumnya bahwa pada beberapa penelitian menunjukkan hasil semakin tinggi dosis ekstrak yang diberikan maka efek yang ditimbulkan juga semakin besar. Hal ini disebabkan karena tingginya dosis yang diberikan sehingga konsentrasi senyawa aktif pada ekstrak juga semakin tinggi dan menyebabkan kemampuan untuk menekan atau daya anti semakin kuat (Purwaningdyah et al., 2015).

Hasil penelitian ini sejalan dengan hasil penelitian Beu et al (2014) tentang uji efektivitas ekstrak etanol tunas pisang goroho (Musa acuminate L.) terhadap penurunan kadar gula darah tikus putih. Hasil penelitian tersebut menunjukkan penurunan kadar glukosa darah yang sangat signifikan dari ekstrak etanol tunas pisang goroho dosis 0,22 $\mathrm{g} / \mathrm{kgBB}$ disebabkan karena dosis ini merupakan varian dosis yang paling tinggi sehingga efek penurunannya paling besar dibandingkan dosis $0,55 \mathrm{~g} / \mathrm{kg}$ BB dan 0,11 $\mathrm{g} / \mathrm{kgBB}$. Bahkan efek penurunan kadar glukosa darah tikus pada pemberian ekstrak etanol pisang goroho dosis 0,22 $\mathrm{g} / \mathrm{kgBB}$ lebih besar dari efek penurunan kadar glukosa darah pada kontrol positif (glibenklamid). Akan tetapi perbedaan ini tidak memberikan perbedaan nyata secara signifikansi antara ekstrak etanol tunas pisang goroho dan glibenklamid, sehingga dapat disimpulkan bahwa ekstrak etanol tunas pisang 
goroho memberikan efek antihiperglikemik yang sama dengan glibenklamid.

Hal ini juga sesuai dengan hasil penelitian Nugroho (2002) bahwa pemberian ekstrak air buah ketumbar dengan dosis terendah yaitu 0.014 $\mathrm{b} / \mathrm{v}$ tidak menurunkan secara bermakna kadar gula darah mencit $(P>0.05)$. Dilain pihak, pemberian dosis tertinggi yaitu $0.035 \mathrm{~b} / \mathrm{v}$ mampu menurunkan secara bermakna $(P<0.05)$ kadar gula darah mencit yang dibebani glukosa. Meskipun demikian efek hipoglikemiknya masih di bawah tolbutamid. Sementara itu pada penelitian Yulianty et al (2015) berdasarkan uji statistika pemberian ekstrak biji ketumbar dosis tertinggi mempunyai efek menurunkan kadar gula darah mencit yang diinduksi aloksan secara bermakna $P<0.05$ hingga kadar gula darah menjadi normal.

Penelitian yang dilakukan Rini et al (2013) juga menunjukkan bahwa semakin tinggi dosis ekstrak putri malu yang diberikan maka semakin rendah kadar BUN dan kreatinin. Dari hasil penelitian yang dilakukan, terlihat bahwa dosis $800 \mathrm{mg} / \mathrm{kg}$ BB adalah dosis yang paling mendekati kontrol positif sehingga kadar BUN lebih rendah dibanding dosis $400 \mathrm{mg} / \mathrm{kg} \mathrm{BB}$ dan dosis $600 \mathrm{mg} / \mathrm{kg} \mathrm{BB}$, sedangkan dosis $400 \mathrm{mg} / \mathrm{kg}$ BB adalah dosis yang mendekati kontrol.

Meski demikian, menurut Fidrianny et al. (2003) bukan berarti semakin tinggi dosis juga akan semakin efektif, karena bisa jadi pada dosis tinggi terdapat zat lain yang mempunyai efek berlawanan dalam jumlah efektif yang memadai, sehingga efek yang muncul lebih kecil. Hal sejalan dengan Kurniawan et al (2014) bahwa hal tersebut diduga terkait dengan banyaknya kandungan senyawa dan bahan aktif yang ada pada ekstrak daun yang kompleks, yang masingmasing bekerja secara tidak spesifik. Hal ini sering dijumpai pada aktivitas ekstrak bahan alam yang merupakan campuran multikomponen, dimana komponen-komponen tersebut dapat saling sinergis atau antagonis. Kemungkinan pada dosis lebih besar, ekstrak dapat memperparah atau tidak berpengaruh.

Sehubungan dengan itu, maka menurut Lusiana et al (2013) dalam mengkonsumsi obat, jamu, dan sejenisnya hendaklah sesuai dengan

\section{Daftar Referensi}

Abdelmoaty, M.A., Ibrahim, M.A., Ahmed, N.S., and Abdelaziz, M. A. 2010. Confirmatory Studies on the Antioxidant and Antidiabetic Effect of Quercetin in Rats. Indian Journal of Clinical Biochemistry, 25(2) pp.188-192.

Brahmachari, G. 2011. Bio-Flavonoids With Promising Antidiabetic Potentials: A dosis karena jika berlebih akibatnya akan dapat merugikan diri kita sendiri. Pemberian kadar dosis yang berlebih dapat menyebabkan senyawa aktif bisa jadi merugikan. Sesuai dengan pernyataan di atas dosis tertentu ternyata dapat bersifat sebagai racun dan dapat pula bersifat sebagai obat.

Tikus memiliki peran yang sangat penting dalam percobaan medis, menurut Foundation for Biomedical Research (FBR) 95\% hewan laboratorium adalah tikus. Ilmuwan dan peneliti bergantung pada tikus karena beberapa alasan salah satunya adalah sebagian besar tikus percobaan medis hampir identik secara anatomi, fisiologi, genetik, karakteristik biologi dan perilakunya sangat mirip manusia serta banyak gejala kondisi manusia dapat direplikasi pada tikus. Tikus mempunyai kemampuan metabolik yang relatif cepat sehingga lebih sensitif bila digunakan dalam penelitian yang berhubungan dengan metabolik tubuh yang didasarkan pada patogenesis penyakit tersebut pada manusia (Kram, 2001).

Pemilihan tikus penelitian idealnya harus dipilih semirip mungkin dengan kondisi manusia, utamanya dalam hal absorpsi, distribusi, metabolisme, dan ekskresi terhadap senyawa yang ada di $T$. diversifolia. Hal ini dilakukan untuk memperkecil perubahan respon antarjenis dan dalam satu jenis tikus terhadap efek senyawa yang ada di T. diversifolia (Monica, 2012).

\section{Simpulan}

Berdasarkan hasil dan pembahasan maka dapat ditarik kesimpulan sebagai berikut. 1) Ada pengaruh ekstrak daun $T$. diversifolia terhadap penurunan kadar glukosa darah tikus Wistar (Rattus norvegicus). Hal ini menunjukkan bahwa daun $T$. diversifolia memiliki efek antidiabetes atau berperan sebagai antihiperglikemik. 2) Pemberian dosis ekstrak daun $T$. diversifolia sebesar 5,14 $\mathrm{ml} / 200 \mathrm{~g}$ BB memiliki pengaruh paling efektif dalam penurunan kadar glukosa darah tikus Wistar (Rattus norvegicus) dengan nilai rata-rata $136,80 \mathrm{mg} / \mathrm{dl}$ atau tidak berbeda nyata dengan perlakuan kontrol negatif atau normal dengan rata-rata $122,20 \mathrm{mg} / \mathrm{dl}$.

Critical Survey. Signpost,pp.187-212.

Chon, H., Peng, L.Y., Jiang, B., Hon, A.J., Lia, Z.W. and Sun, H.D. 2000. Chemical constituents from Tithonia diversifolia. Yannan Zhiwu Yanjiu, 22 pp.361-364.

Choudhary, M.I. 2001. New a-glukosidase inhibitors from the Mongolian medicinal plant Ferula mongolica. Helvecita Chimica Acta, 84(8) pp.2409-2416. 
Dalimartha, S. 2000. Atlas Tumbuhan Obat Indonesia. Jakarta: Trubus Agriwidya.

Depkes RI. 2014. Situasi dan Analisis Diabetes. Jakarta: InfoDATIN, Pusat Data dan Informasi Kementerian Kesehatan RI.

Dheer, R. and Bhatnagar, P. 2010, A study of the Antidiabetic Activity of Barleria prionitis Linn. Indian Journal of Pharmacology, 42(2) pp.70-73.

Fidrianny, I., Padmawinata, K., Soetarno, S. and Yulinah, E. 2003. Efek Antihipertensi dan Hipotensi beberapa Fraksi dari Ekstrak Etanol Umbi Lapis Kucai (Allium schoenoprasumL., Lliliaceae). Jurnal Matematika dan Sains, 8(4) pp.147-150.

Gheith, O., Farouk, N., Nampoory, N., Halim, M.A., and Al-Otaibi, T. 2016. Diabetic kidney disease: world wide difference of prevalence and risk factors. Journal of Nephropharmacology, 5(1) pp 49-56.

Hanum, I.F. and van der Masen, L.I. G. 2002. Auxiliary Plants. J.Nat.Prod, 2002 pp.297-298.

Hidayat, S. and Napitupulu, R.M. 2015. Kitab Tumbuhan Obat. Jakarta: Agriflo.

Indariani, $\quad$ S. $2011 . \quad$ Aktivitas AntihiperglikemikMinuman Fungsional Berbasis EkstrakDaun Kumis Kucing (Orthosiphon aristatus Bl.Miq)pada Mencit Hiperglikemikyang Diinduksi Dengan Streptozotocin.Tesis tidak diterbitkan. Bogor: Sekolah Pascasarjana, Institut Pertanian Bogor.

Jagtap, U.B. and Bapat, V.A. 2010. Artocarpus: A review of its traditional uses, phytochemistry and pharmacology. Journal of Ethnopharmacology, 129 (2010) pp.142-166.

Jamal, Y. and Agusta, A. 1999. Komponen Kimia Dan Uji Daya Antibakteri EkstrakDaun Kirinyu (Tithonia diversifolia). Bogor: Laboratorium Treub,Puslitbang BiologiLIPI.

Kram, D.J. and Keller, K.A. (Eds). 2001. Use of laboratory animals in toxicology studies. In: Toxicology testing handbook. New York, USA: Marcel Dekker.

Kurniawan, B., Carolia, N., Sukohar, A. and Thamrin, A.P.Y. 2014. Antiinflammatory Effectiveness of Binahong Leaves Extracts(Anredera cordifolia (Ten.) Steenis) in Male Sprague Dawley Rats Induced byCarrageenan. Naskah Publikasi. Bandar Lampung: Fakultas Kedokteran UNILA.
Li, H.Y., Hou, F.F., Zhang, X., 2007. Advanced oxidation protein products accelerate renal fibrosis in a remnant kidney model. Journal of the American Society of Nephrology, 18(2) pp.528-538.

Lusiana, Dhafir, F. and Masrianih. 2013. Pengeruh Pemberian Ekstrak Daun Pegagan (Centella Asiatica) Terhadap MotilitasSpermatozoa Mencit (Mus Musculus) Galur Ddy. e-Jipbiol, 2 pp.2429.

Marianne, Yuandani and Rosnani. 2011. Antidiabetic Activity From Ethanol Extract Of Kluwih's Leaf (Artocarpus camansi). Jurnal Natural, 11(2) pp.6468.

Monica, P.W. 2012. Efek Sitotoksik Ekstrak Etanol T. diversifolia (Hemsley) A. Gray. Terhadap Sel WiDR Dibandingkan 5Fluorouracil. Skripsi tidak diterbitkan. Yogyakarta: Fakultas Kedokteran Universitas Gadjah Mada.

Oktaria, Y.E. 2013. Uji Aktivitas Antidiabetes Ekstrak Etanol Biji Alpukat (Persea americana Mill.) Terhadap Tikus Galur Wistar yang Diinduksi Aloksan. Makalah. Surakarta: Fakultas Farmasi Universitas Muhammadiyah Surakarta.

Panjuantiningrum, F. 2010. Pengaruh pemberian buah naga merah (H.Polyrhizus) terhadap kadar glukosa darah tikus putih yang diinduksi aloksan. Skripsi tidak diterbitkan. Surakarta: Fakultas Kedokteran Universitas Sebelas Maret.

Piwowar, A., Knapik-Kordecka, M. and Warwas, M. 2009. Markers of oxidative protein damage in plasma and urine of type 2 diabetic patients. British Journal of Biomedical Science, 66 (4) pp.194-199.

Powers, A. 2001. Dibetes Mellitus. Dalam Braunwald, E., Fauci, A., Kasper, D., Hauser, S., Longo, D. \& Jameson, J. Harrison's Principles of Internal Medicine. $15^{\text {th }}$ Edition. New York: McGraw-Hill.

Pradeep, K. R., Sujatha, D., Saleem, T. S. T, Chetty, C. M. and Ranganayakulu, D. 2010. Potential hypoglycemic \& hypolipidemic effect of Morus Indica and Asystasia gangetica in Alloxan induced diabetes mellitus. Int. J. Res. Pharm. Sci., 1 pp.51-56.

Purnamasari, D. 2009. Diagnosis dan Klasifikasi Diabete Mellitus. Dalam: Sudoyo, A.W, Setiyohadi, B., Alwi, I., Marcellus, S. K., \& Setiati, S. (Eds). Buku Ajar Ilmu 
Penyakit Dalam. Jld 3 Ed. 5. Jakarta: Interna Pub.

Purwaningdyah, Y. G., Widyaningsih, T. D. and Wijayanti, N. 2015.Efektivitas Ekstrak Biji Pepaya (Carica papaya L.) Sebagai Antidiare pada Mencit yang Diinduksi Salmonella typhimurium. Jurnal Pangan dan Agroindustri, 3(4) pp.1283-1293.

Putri, N. H. K. and Isfandiari, M. A. 2013. Hubungan Empat Pilar Pengendalian DM Tipe 2 dengan Rerata Kadar Gula Darah. Jurnal Berkala Epidemiologi, 1(2) pp.234-243.

Ridwan, A., Astrian, R. T. and Barlian, A. 2012. Pengukuran efek antidiabetes polifenol (polyphenon 60) berdasarkan kadar glukosa darah dan histologi pankreas mencit (Mus musculus) s.w. jantan yang dikondisikan diabetes mellitus. Jurnal Matematika dan Sains, 17(2) pp.78-82.

Rini, A. S., Hairuddin and Sugiyanta. 2013. Efektivitas Ekstrak Putri Malu (Mimosa pudica Linn.) sebagai Nefroprotektor pada Tikus Wistar yang Diinduksi Parasetamol Dosis Toksik. Jurnal Pustaka Kesehatan, 1(1) pp.15-19.

Ruhe, R. C. and McDonald, R. B. 2001. Use of antioxidant nutrient in the prevention and treatment of type 2 diabetes. J. Am. Coll. Nutr., 20(5) pp.363-369.

Saadane, A., Masters, S., Di Donato, J., Li, J. and Berger, M. 2007. Parthenolide inhibits $\mathrm{I} \kappa \mathrm{B}$ kinase, NF- $\kappa \mathrm{B}$ activation, and inflammatory response in cystic fibrosis cells and mice. American Journal of Respiratory Cell and Molecular Biology, 36(6) pp.728-736.

Sanbrook, J. and Russell, D. 2001. Molucelar Cloning: a Laboratory Manual. 3rd Edition. New York: Cold Spring Harbor Laboratory.

Shaw, J.E., Sicre, R.A. and Zimmet, P.Z. 2010. Global estimates of the prevalence of diabetes for 2010 to 2030. Diabetes Research and Clinical Practice, 87 (2010) pp.4-14.

Sinaga, A.F., Bodh, W. \& Lolo, W. A. 2014. Uji Efek Ekstrak Etanol Daun Salam (Syzygium polyanthum (Wight.) Walp) Terhadap Penurunan Kadar Asam Urat Tikus Putih Jantan Galur Wistar (Rattus novergicus L.) yang Diinduksi Potasium Oksonat. PHARMACON Jurnal IImiah Farmasi, 3(2) pp.141-145.

Syamsul, E. S., Nugroho, A.E. and Pramono, S. 2011. Aktivitas Antidiabetes Kombinasi
Ekstrak Terpurifikasi Herba Sambiloto (Andrographis paniculata (Burn.F.) NESS.) dan Metformin Pada Tikus DM Tipe 2 Resisten Insulin. Majalah Obat Tradisional, 16(3) pp.124-131.

Taufiqurohman. 2015. Indonesian Bay Leaves as Antidiabetic for Type 2 Diabetes Mellitus. J. MAJORITY, 4(3) pp.101-108.

Thongsom, M., Chunglok, W., Kuanchuea, R. and Tangpong, J. 2013.Antioxidant and Hypoglycemic Effects of Tithonia diversifolia Aqueous Leaves Extract in Alloxan-induced Diabetic Mice. Advances in Environmental Biology, 7(9) pp.2116-2125.

Chou, Aria, M., and Novicaresa, M. 2011. Aktifitas Anti Inflamasi Ekstrak Etanol Daun Kembang Bulan (Tithonia diversifolia. A. Gray) Terhadap Mencit Putih Betina. SCIENTIA, 1(1) pp.47-52.

Wang, J. C., Zhao, Y. \& Chen, S. J. 2013. AOPPs induce MCP-1 expression by increasing ROS-mediated activation of the NFkappaB pathway in rat mesangial cells: inhibition by sesquiterpene lactones. Cellular Physiology and Biochemistry, 32(6) pp.1867-1877.

Widowati, W. 2008. Potensi Antioksidan sebagai Antidiabetes. Jurnal Kedokteran Marantana, 7(2).

Wild, S., Roglic, G., Green, A., Sicree, R. and King, H. 2004. Global prevalence of diabetes: estimates for the year 2000 and projections for 2030. Diabetic Care, 27(2004) pp.1047-1053.

Winarsi, H., Sasongko, N. D., Purwanto, A. and Nuraeni, I. 2013. Ekstrak Daun Kapulaga Menurunkan Indeks Atherogenik dan Kadar Gula Darah Tikus Diabetes Induksi Alloxan. AGRITECH, 33(3) pp.273-280.

Winarsi, H., Sasongko, N. D., Purwanto, A., Arinton, I. G. and Nuraeni, I. 2012. In vitro antioxidant activity of the stem and leaves Amomum cardamomum extracts. International Conference on Medicinal Plants. Purwokerto, 11-13 October.

Witko-Sarsat, V., Friedlander, M., and Khoa, T. N. 1998. Advanced oxidation protein products as novel mediators of inflammation and monocyte activation in chronic renal failure. The Journal of Immunology, 161(5) pp.2524-2532.

Yang, L., Liang, M., and Zhou, Q. 2010. Advanced oxidation protein products decrease expression of nephrin and podocin in 
podocytes via ROS-dependent activation of p38 MAPK. Science China Life Sciences, 53(1) pp.68-77.

Yulianty, O., Sudiastuti, and Nugroho, R. A. 2015. Efek Ekstrak Biji Ketumbar (Coriandrum sativum L.) terhadap Histologi Pankreas Mencit (Mus musculus L.) Diabetik Aloksan. Prosiding Seminar Tugas Akhir FMIPA UNMUL 2015 Periode Juni 2015, Samarinda.
Zhang, X.F., and Tan, B.K. 2000. Antihyperglycemic and anti-oxidant properties of Andrographis paniculata in normal and diabetic rats. J. Clin. Exp. Pharmacol. J. Physiol, 27(3) pp.58-63.

Zhao, G., Li, X., Chen, W., Xi, Z., and Sun, L. 2012. Three new sesquiterpenes from Tithonia diversifolia and their antihyperglycemic activity. Fitoterapia, 83 pp.1590-1597 